\title{
The Temporality of (Serialized) Romantic Comedy
}

\author{
CAROLINA AMARAL, Universidade Federal Fluminense
}

\begin{abstract}
Romantic comedies have a temporal structure based on suspense that I call temporality of the almost: the micro-narrative structure that repeatedly makes erotic resolution almost happen at several points in the story. This article analyzes how this temporality of constant and continual deferral functions as a retardatory structure posing obstacles apparently in order to keep characters apart, but, in fact, increasing the desire between them, and also between narrative and spectators.
\end{abstract}

\section{KEYWORDS}

Narrative, Temporality, Almost, Romantic Comedy, Suspense.

\section{Introduction}

I see in the plots we invent the privileged means by which we re-configure our confused, unformed, and at the limit mute temporal experience. "What, then, is time?" asks Augustine. "I know well enough what it is, provided that nobody asks me; but if I am asked what it is and try to explain, I am baffled." In the capacity of poetic composition to re-figure this temporal experience, which is prey to the aporias of philosophical speculation, resides the referential function of the plot.

Paul Ricoeur in Time and Narrative $(1984, \mathrm{xi})$

This article is about time and a specific kind of narrative: romantic comedies, the temporal structures of romantic comedies and how they organize love in a narrative. Therefore, I will define romantic comedy as a comic love narration. A love narration is usually told from the first meeting of the lovers to a resolution. Broadly speaking, two such resolutions are the most common: marriage and death, corresponding respectively to a comic approach or a tragic one. The comic version brings an optimistic worldview to the story, commonly mixed up with the happy ending convention.

If, as suggested by Ricoeur, narrative is a way human beings have devised to organize time, this article aims to explain how narrative conventions in romantic comedies - with actions well-known as meet, lose and get - are translated into temporal structures. The genre combines the instant of the first encounter, with the ever after of the happy ending, and repetitions of the middle part. It permits translate into narrative terms, affects and emotions such as love and desire. The central conceptual proposition here is that romcoms use a temporal structure based on suspense called temporality of the 
almost (Amaral, 2018): the micro-narrative structure that repeatedly makes erotic resolution almost happen at several points in the story. This temporality of constant and continual deferral functions as a retardatory structure apparently posing obstacles in order to keep characters apart, but, in fact, increasing the desire between them, and also between narrative and spectators.

\section{Temporal connections in romantic comedies}

Love stories generally begin with a meaningful first encounter between the lovers. It is also a convention that this encounter is combined with the mystic of a "love at first sight", even when the significance of this first moment is revealed only later on, when the couple reach a happy ending. This encounter is what screenplay manuals have named the inciting incident: "the first major event of the telling, is the primary cause for all that follows, putting into motion the other four elements - Progressive Complications, Crisis, Climax and Resolution" (Mckee, 1997, p. 181). Love at first sight justifies the moment when everything changes. This first encounter turns something almost "magic" as love at first sight into a narrative scene, with actions and dramatic consequences to explore. There is strength and simplicity both in the imagistic and narrative proposals of a first meet: "something insignificant in appearance, but, in reality, a radical event in microscopic life" (Badiou, 2013, p. 31). It is a break of the routine, an invitation to a journey. In Hollywood romantic comedies this point is so conventional that it even has a name, the meet cute: a meet or a series of meets between the central couple which stars the whole story (Mernit, 2001). Thus, the meet cute, this moment when everything changes, can be interpreted in temporal terms as an instant, a thunderbolt, directly related to the coup de foudre of love at first sight.

At the other end of the story frame in a romantic comedy is the happy ending. It inscribes that initial instant with a promise of eternal bliss through the myth of romantic love. Romantic love is forever - until it is not - and it brings to the love story the temporal dimension of divine time, the eternal consummation of blissful happiness. So, what unites the instant (love at first sight) to the eternal (happy ending) in love stories is the narrative work of the middle - the usually forgotten middle (Brooks, 1984) - which comprises most of the narrative and stabilizes its meaning ${ }^{1}$. In the middle part resides the temporality of the almost, as I will explain latter on.

In a passionate description of what love might be, French philosopher Alain Badiou highlights that the reason it is so intense is because it attempts to inscribe its eternal potential into a duration. Inspired by Mallarmé, who considered poetry to be "chance defeated word by word" (apud. Badiou, 2012, p. 45), Badiou believes that chance is curbed with a grand gesture: a declaration of love. Many romantic comedies end with

${ }^{1}$ As Deleyto (2009, p.24) puts it, attention to the middle section will also allow us to explore the important role of humor in romcoms and the flexibility of the genre, and it will help to abandon the ideological determinism critical discussions of the genre usually reproduce. 
this moment, when characters declare I love you or yes, I do, sentences that are more than just words - they are performative utterances since to say something is to do something (Austin apud Schechner, 2006, p. 123).

If "I love you" is always, in most respects, the heralding of "I will always love you", it is in effect locking chance into the framework of eternity. We shouldn't be afraid of words. The locking in of chance is an anticipation of eternity. And to an extent, every love states that it is eternal: it is assumed within the declaration... The problem then resides in inscribing this eternity within time. Because, basically, that is what love is: a declaration of eternity to be fulfilled or unfurled as best it can be within time: eternity descending into time. That's why it is such an intense feeling (Badiou, 2012: 47).

Romantic comedy is a narrative in which the adventure functions exactly to unite the instant to the eternal. It builds a dramatic logic, in conventional terms, between meet cute and happy ending. In other words, "the locking in of chance" in a comic story. The understanding of narrative structures and the work of humor will clarify this idea.

Although comedy is a central feature in a romcom, sometimes its importance can be taken for granted. I would like to underline the role of comedy in the genre. Comedy is what makes happy endings possible. The happy ending is not just something that happens at the end; rather it affects the atmosphere of the whole story. Corrigan (1981) says that the only thing present in all comedies is not a narrative structure or effect, but an optimistic attitude facing the troubles and challenges the world might impose. Susanne Langer (1981) goes further and compares the rhythm of comedy with the rhythm of life due to its festive attitude: "the same impulse that leads people since prehistorical times to celebrate happiness rites and all biological phases of our existence is what sustains the eternal interests in comedy" (p. 82).

Therefore, comedy can be seen as encapsulating an optimistic worldview. Deleyto (2009) uses this idea to understand how romantic comedies work: by constructing a narrative space within the story, a safe, benevolent, better and freer space, where all our inhibitions and inadequacies are forgotten and all desires can be fully and fearlessly lived. The author (2009, pp. 31-37) calls this "comic space". Comic space is the magic space of the romantic comedy and it is built bit by bit by the narrative. It welcomes characters to enjoy their desires freed from day-to-day hindrances. In fact, desire is indispensable in narrative. Characters must desire something so that the story can move on. Discussing characters and storytelling, screenwriter John Truby (2007, p. 7) has adapted the Cartesian cogito to "I want, therefore I exist". New information makes characters act continuously to attain (or not) their desire at the end. Narrative desires differ from text to text. In a romantic comedy, the convention is that characters' desires are erotic desires, although this desire is never reduced to sex only. The comic space is constructed by the narrative to satisfy the characters' desires and make the happy ending possible. Comic space changes the environment by, as the story progresses, making it favorable for the expressions of love and desire. It also allies with another narrative strategy: characters' transformations. An example will clarify this idea. Tootsie (1982) 
is not frequently remembered as a romantic comedy. Maybe because, in this film, the protagonist's transformation is bigger than his love story. But the two things happen together, as well as the formation of comic space, if we interpret it as a romantic comedy - that is as a comic love narration. Tootsie tells the story of Michael Dorsey (Dustin Hoffman), a cynical and selfish actor who can no longer find an acting job in New York because of his temperament. So he dresses himself as a woman, Dorothy, to do an audition for a daytime soap opera. He gets the job and starts to work with Julie (Jessica Lange), a sweet and sad costar in the soap opera. They become friends, but Michael falls in love with Julie. Acting as if he was Dorothy, Michael changes. Not only is he more affectionate and caring, but he also manages to change the work environment of the soap opera with his character's improvisations within the story. Julie's friendship with Dorothy makes her stronger and more confident. They both change and although a romantic relationship between them seems impossible, a magic space that permits characters to be sincere, freer and honest is formed. They are being true to themselves, even if, ultimately, Michael is lying about his identity. There is a convention in romantic comedy that characters tell the truth through lies; and that is why masquerades and other disguises are so common in the genre. Characters achieve better versions of themselves pretending to be someone else, and that changes the fictional space around them.

While Julie terminates her toxic relationship with the soap opera's director, Michael ceases to be the arrogant and self-absorbed narcissist he was at the beginning. At the climactic point Michael reveals the truth to Julie during a live recording episode. She slaps him. Time passes and when they finally meet again, Julie says she misses Dorothy and he answers with these now famous lines:

You don't have to. She's right here. And she misses you. Look, you don't know me from Adam. But I was a better man with you, as a woman... than I ever was with a woman, as a man. You know what I mean? I just gotta learn to do it without the dress. At this point, there might be an advantage to my wearing pants. The hard part's over, you know? We were already... good friends.

The comic space permits characters to be better people and freely experience their desires. Michael was so desperate to find an acting job that his whole life became a role to play. Normally, the comic space is formed on the basis of romantic love and the powers of the comic, but it can also be the result of friendship. For example, in Sex and the City (1998-2004) the protagonists' friendship is what protects them and encourages them to engage in erotic fantasies and love adventures. The romcom genre combines characters' transformation and the creation/formation of a comic space. In Tootsie the comic space is the result of friendship and romantic love between the protagonists and the intimacy they share.

The deployment of comic space coincides with the narrative transformation towards the happy ending - in temporal terms, eternity. However, the formation of a comic space takes time. A place where desires are fulfilled all the time does not correspond to the dynamic nature of narrative. That is why the comic space is continuously charged with threats of not being complete. Temporal control develops the erotic function of 
narrative: it prevents desires from being completely fulfilled during the story, but also permits partial satisfaction. Like striptease, romantic comedy undresses piece by piece before exposing the naked vulnerability of its characters.

\section{Suspense and obstacles}

Time and space are basic elements of narrative. It has been shown that narrative space in a romantic comedy is related to characters' transformation and the emergence of a comic space. The most important temporal question is: when will the narrative fulfil the character's desires? Therefore, it is common that the fulfilment of desire is also the end of the story. In the meantime, between characters and their desires we have obstacles furthering narrative dynamics. We follow the "successive desire march" (Brooks, 1984) through obstacles. By overcoming these obstacles characters are transformed. Obstacles are a practically omnipresent element in any narrative universe, and they acquire particular relevance in comic formats. For Frye (1973) obstacles to the hero's desires are what results in a comic action. Bakhtin (1981), for his part, associates this kind of narrative to the adventure novel, where obstacles retardate the final couple's union. For Meir Sternberg (1978), obstacles in the hero's way to a happy ending retardate the couple's final union in both the adventure novel and comedy. Sternberg describes this use of obstacles as a retardatory strategy we all intuitively know: suspense.

Although romantic comedies are not analyzed by Sternberg, we may affirm that obstacles to the final couple in the genre work in the same way as described by this and other authors. But romcom combines this strategy with its own conventions, making erotic desire coincide with narrative desire. Erotic desire, often under the guise of "true love", leads characters to take risks, challenge boundaries and accept narrative transformation. Obstacles, which on the surface seem a way to tear couples apart, actually function in romantic comedies as desire propellers. In many examples, characters are their own obstacles and that is why they have to change to pursue their objectives. This type of obstacles - screenplay's manuals call it internal obstacles function by translating complex internal conflicts into action.

Comparing obstacles in romance genre and in romcoms may make this clearer. Love at first sight is a convention of the romance genre as well. In romcoms this crystalizes in the meet cute, a scene filled with chemistry and tension that often activates the notion of love at first sight in order to confirm it at the end. Thus, obstacles in romances are a real barrier while in romantic comedies they create excitement, an electric feeling that leads to final joy. A Marriage Story (2019) may be considered a romance drama in which the happy ending for the woman is divorce. At the beginning, we are presented to the main characters with both man and woman telling us what first attracted them to each other. So, we know what kept them together until now and this relatively short introduction feature the great couple they might be. Then, throughout the film the obstacles to this romance are revealed to the audience during the process of divorcing. These obstacles are formidable and gradually we realize that they will prove insurmountable. The couple 
is already broken and obstacles do not create enthusiasm or suspense, even if divorce constitutes the happy ending.

In romcoms, on the other hand, the comic space makes love and attraction not only safe but mandatory. In romantic comedy, the interposition of obstacles keeps the desire impulse strong. It also imposes a rhythm, chopping the main action with impeding events until it reaches the climax. Sternberg (1978, p. 159) describes suspense as a narrative temporal control which functions exactly like this:

one of the prime means of creating, intensifying, or prolonging suspense consists in the author temporarily impeding ("suspending") the natural progression of the action, especially, its onward rush toward some expected climax, by the interposition of more or less extraneous matter.

Since it is part of the information distribution strategy, suspense is used in a variety of narrative forms, although it is characteristic of detective stories and other variants of the thriller genre. In detective stories, the climax is generally the exposition of the story, that is, the access to the totality of the fictional universe through explanation to the spectator, something that in other genres we find at the beginning. In many detective stories, characters' transformations are secondary regarding the information management of the plot. On the contrary, romantic comedies do not seek a great revelation towards the end and do not need a great amount of exposition for the audience to access the plot like political thrillers, or historical dramas. What appears in a funny and involving way in the genre is how characters deal with their own desires and objections to them, providing a coherent and gradual transformation. It is what Mernit (2001) calls "intimate journeys": characters evolve, and this mutual transformation combines with the main plot. Sternberg (1978) denominates this kind of narrative staircase-like construction, where the suspense composition is formed by obstacles that prevent the hero's success, with the end always postponed step by step. The more numerous or formidable the obstacles, the greater the retardatory effect of suspense.

Besides suspense, other temporal control strategies are curiosity, surprise and anticipation; they manipulate time in order to cause an effect in the audience, creating expectations between public and texts. While suspense projects information and actions to the future, prolonging time, surprise appears suddenly, like a shock. Suspense delays a conclusion and increases its gratification when it happens (Lavandier, 2003) while surprise presents a too short gratification but impresses through what Lavandier (2003) calls the "stroke effect".

On the other hand, curiosity (Sternberg), also called mystery (Lavandier), denies information about the past leaving behind a big question mark for those who follow the story. It also hierarchizes characters that know better than spectators. Finally, anticipation, as suggested by its name, anticipates crucial information about events that will happen later on in story, a mechanism often used in melodramas. With anticipation the audience knows better than the characters. Melodramas use anticipation as their key temporal control strategy: when the protagonist discovers important information we already know, it is frequently "too late" to do anything. 
In horror movies, suspense is used to build tension and fear, but the genre's characteristic strategy is surprise: suddenly and "too soon" the monster appears and surprises everyone. Linda Williams ([1991] 2003) has called these temporal narrative strategies used by genres temporalities. Williams has studied specific genres such as melodrama, horror film and pornography, which she has labeled body genres due to the fact they incite corporal reaction in the audience such as orgasm, weeping and terror. For Williams, when dealing with body genres, spectators mimic similar reactions, performing an embodiment with the movies. This interplay between body genres and the audience is completed by the temporalities of each genre, making things happen "too late" in melodramas, "too soon" in horror movies and "on time!" in porn, which displays perfect timing between desire and performance.

Later (2001), Williams published an extensive study on melodrama recognizing its cardinal importance in American cinema. Williams observes that in melodrama, victims suffering and being saved perform the spectacle of pathos and action, and everything happens hopelessly too late. Even when resorting to a strategy like suspense, what prevails is the story's temporality, with "the teasing suspenseful retardation of the outcome constantly threatening that it must by now, certainly, be too late" (ibid., p. 35). The author emphasizes that the audience may cry even in happy ending melodramas because the "too late" temporality is already functioning, and it does not matter that "hope against hope, desire is fulfilled, and time is defeated" (p. 31).

By conceptualizing body genres, Williams claims that temporalities rule generic expectations in the audience. She does not analyze comedy, the thriller or musicals, but she recognizes those as body genres, too. If we read the romantic comedy as a body genre, we may imagine the kind of reaction it provokes through its characteristic temporality. I call the temporality of romantic comedy's the temporality of the almost (Amaral, 2018), because this continuous retardation, produced by suspense - with the interposition of obstacles in a staircase-like construction - makes the couple almost get together many times throughout the story. It suspends a linear action and deals with narrative and erotic climaxes. The temporality of the almost in romantic comedies is responsible for organizing this transformation of an instant into eternity through narrative duration. It retards a favorable resolution to the story, joining the characters' erotic desires with the reader's narrative cravings. It is described as almost because the happy ending is repeatedly postponed but remains close at hand. By means of this structure, the instant and the eternal remain present but can be transformed into narrative duration.

It is, somehow, a repetitive structure and yet, repetition is also a narrative strategy, slightly varying from time to time (Brooks, 1984). Moreover, Badiou (2012, p.20) recognizes how repetition is a basic structure for love as "one must start time and time again". For the author, it is necessary to declare love over and over, to restart it: "desire is immediately powerful but love also requires care and re-takes" (p. 53). Lynne Pearce (2001) also argues that love is traditionally seen as unique, but that in fact everything about it is wanting "the same again". For Pearce, love is understood only in terms of 
repetition. Even love stories that celebrate a non-repeatable love can be repeated. After all, this is what "Western civilization has most wanted to hear" (Pearce, 2001, p. 7).

Thus, the almost organizes temporal tensions such as the instant, the forever, the narrative and the repetition. The temporality of the almost is what unites beginning and end, corresponding to the most forgotten part of a romantic comedy: the middle. Again Brooks (1984) recaps the forgotten middles in his analysis of plot, because it is precisely the middle that contains the temporal dynamic of narrative, "the desires that connect narrative ends and beginnings, and make of the textual middle a highly charged field of force" (1984). Brooks calls upon psychoanalytical theory to prove that the middle is charged with tensions and carries the desire that is established at the beginning towards the end: "As with the play of repetition and the pleasure principle, forward and back, advance and return interact to create the vacillating and apparently deviant middle" (Brooks, 1984). In romantic comedies, the almost develops this vacillating work between ends and beginnings.

In the romantic comedy genre, the characters' narrative transformation permeates all narrative space, as was seen in the concept of comic space. However, this narrative pinnacle must happen in an exciting climax; protagonists must give up or accept repeatedly the challenge of being transformed. The almost is responsible for making the feel-good moment of the end even more pleasurable. But what happens if the romantic comedy lasts much longer than ninety minutes, and is told year by year?

\section{Serialized fiction and the romantic comedy}

In the Arabian Night tales, Scheherazade, the vizier's oldest daughter, volunteers to marry the king who has sworn he would marry a girl every night and kill her in the morning after to avoid being cheated again. Scheherazade has a plan to ensure her life is spared: to tell a very interesting story every night and interrupt it at a climactic moment as dawn is breaking. After the first night, the king is so captivated by the story that he cannot kill her and waits until the following night to know the resolution. However, Scheherazade repeats the same ploy over and over, beginning new stories and playing with the king's curiosity. Thus, after one thousand and one nights, she has saved her life and the life of all girls of the kingdom because the king is convinced to keep her as his wife.

The story of Scheherazade and many others in the One Thousand and One Nights create cliffhangers where telling a story is the only way to avoid imminent death. It also serves as a good metaphor for serialized fiction: the audience must be interested, even when the story is paused for a moment. While telling a story and postponing its end to the following night, Scheherazade is using a narrative strategy that has already been analyzed here: suspense. Suspense in serialized fiction normally teases the readers'/spectators' desire to know more: every end of chapter/episode is a temporary end and audiences are still connected to the story even when it is not being told. As Brooks (1984) puts it: "the intentionality of plot lies in its orientation toward the end, even while the end must be achieved only through detour". 
Brooks describes these detours as the "arabesques" of plot, the forces of the middle that retard the resolution. The specific form this arabesque takes in romantic comedy is the "temporality of the almost". Although romantic comedies have a long history in cinema and in theater - that goes back to at least Shakespeare - the genre can be easily adapted to a serialized format. This is what happens hundreds of times in serial plots through the well-known formula of "will they won't they", when characters perform a long courtship that the audience can engage with and relate to.

In the final part of my essay, I would like to bring together the almost of romantic comedy and the cliffhanger of serialized fiction. When postponing the final love resolution of a couple, but making it almost happen many times in the narrative, serialized fiction is using a romantic comedy plot and a romantic comedy temporal strategy. This can happen in a romantic comedy series, such as Crazy Ex-Girlfriend (2015-2019), a sitcom like Friends (1994-2004), The Office (2005-2013) or Cheers (1982-1993), a procedural like Ally McBeal (1997-2002), a fantasy drama like Smallville (2001-2011) or a thriller like You (2018-).

The success of the American version of The Office is multifactorial, but it is not wrong to bet on the work of romantic comedies' conventions as a key one, notably, in its early seasons. The temporality of the almost is what structures the plotline of characters Jim (John Krasinsky) and Pam (Jenna Fisher). Their romance is not the main line of action of most episodes, but it gives a thin line that pervades all three first seasons. Larry Wilmore (2020), one of the show's screenwriters, considers it a romantic comedy because its dramatic center is the story of these two characters, a story of intimacy and seduction. For Wilmore (2020), romcom conventions bring up emotional dilemmas that take conflicts to the next level: they are always there even if not mentioned.

This adaptability is due to the fact that a romantic comedy plot can be mixed with other plots, it even does not need to be the main line of action. The comic love narration can be mingled with other universes and still be identifiable. It also elucidates a characteristic of any genre: "Genres are not groups of films, but abstract systems formed by elements taken from many films. The generic bag contains conventions, structures, narrative patterns" (Deleyto, 2009, pp. 12-13). Mostly, genres are conventions that meet in films, plays, TV series, and books. They are a complex communication system that can bifurcate into new directions and reinvent themselves.

Among many storytelling strategies, romantic comedy's almost is one of the commonest in a plethora of TV series in which romcom conventions appear in combination with many other genres. The genre flares up in other narrative universes, keeping the temporal construction which unites love at first sight and (potential) happy ending, almost happening several times in narrative detours.

In serialized fiction, the hiatus between episodes and seasons is also part of the temporal game between audience and story, which is filled with expectations. There is a narrative desire to know more that can be combined with the desire characters feel for each other. In serial formats, characters flirting for a while, and eventually engaging in a 
relationship, does not need to be plot A of the story, but certainly, implies two things: it needs time to happen, customarily, seasons; and while rooting for these characters to be together, the audience in some level engage with the story. In TV series, the pleasures of delays that make things almost happen benefit from a relationship with the spectator that also happens in time. That is why romantic comedy plots and their postponed desires are so present in TV series: it is a well-known structure that spectators can engage with even when they are not completely aware of its deployment.

"What, then, is time?" is the question Augustine asks himself in Ricoeur's quote. If we go back to Ricoeur's notion that narrative is a powerful way to understand time, which opened this article, the temporality of the almost helps us understand multiple temporal possibilities within a comic love narration: instant, eternal and repetition. It also creates and popularizes a pleasant structure that helps people to deal with a traditional magical idea of love and happiness coupled with the narrative logic of characters' transformation. Romantic comedies convert into action (scenes, characters, conflicts) an optimistic view of love and desire. The model, as shown before, is efficient and flexible. Romantic comedy's temporal/narrative structure privileges/celebrates new engagements and new possibilities of happiness and pairing. If, ultimately, every narrative plays a game with its audience placing expectations and then presenting resolutions, the temporal control performed by the almost does that in its own way. It also makes spectators engage with the story. Not only as long as it is been told, but also, after the story is over. The relationship between the audience and romcoms is still on after the ever after.

\section{References}

A Marriage Story (2019) [Film]. Los Angeles: Noah Baumbach.

Ally McBeal (1997-2002) [TV programme]. Hollywood: 20th Century Fox Television.

Amaral. C. (2018). O espaço-tempo da comédia romântica. PhD. Universidade Federal Fluminense.

Badiou, A. and Truong, N. (2012) In Praise of Love. London: Serpent's Tail.

Badiou, A. and Truong, N. (2013) Elogio ao amor. São Paulo: Martins Fontes.

Bakhtin, M. (1981) Forms of Time and the Chronotope in the Novel (1938-73). In: M. Holquist, ed., The Dialogic Imagination: Four Essays. Austin: University of Texas Press.

Brooks, P. (1984) Reading for the Plot: Design and Intention in Narrative. 1st ed. [ebook kindle] New York: Knopf.

Cheers (1982-1993) [TV programme] Hollywood: NBC.

Corrigan, R. W. (1981) Introduction: Comedy and Comic Spirit. In: R. W. Corrigan, ed., Comedy: Meaning and Form, $2^{\text {nd }}$ ed., New York: Harper and Row., pp 1-13. 
Crazy Ex-girlfriend (2015-2019) [TV programme] Hollywood: CW.

Deleyto, C. (2009) The secret life of romantic comedy. Manchester and New York: Manchester University Press.

Fischer, J. and Kinsey, A. (2020) \#Performance Review w/ Larry Wilmore. [podcast]. \#Office Ladies. Available https://open.spotify.com/episode/086C8FaPGm43us5Adi5Wmp?si=ggtgEdEVS OCS-E4HlaN5dA [accessed $6^{\text {th }}$ Apr. 2020].

Friends (1994-2004) [TV programme] Hollywood: NBC.

Frye, N. (1973) Anatomia crítica. São Paulo: Cultrix.

Langer, Susanne. (1981) The Comic Rhythm. In: R. W. Corrigan, ed., Comedy: Meaning and Form, $2^{\text {nd }}$ ed., New York: Harper and Row., pp 67-82.

Lavandier, Y. (2003) La Dramaturgia. Madrid: EIUNSA.

Livro das Mil e uma Noites - Ramo Sírio, (2017) 1st ed. [ebook kindle] São Paulo: Biblioteca Azul.

Mckee, R. (1997) Story: Substance, Structure, Style and the Principles of Screenwriting. New York: HarperCollins.

Mernit, B. (2001) Writting the romantic comedy: from "cute meet" to "joyous defeat" how to write screenplays that sell. New York: Harper.

Pearce, L. (2011) Romance and Repetition: testing the limits of Love. Journal of Popular Romance Studies from the international Association for the Study of Popular Romance. [online] Issued 2.1. Available at: http://jprstudies.org/2011/10/\%E2\%80\%9Cromance-and-repetition-testing-thelimits-of-love\%E2\%80\%9D-by-lynne-pearce/ [Accessed 18 Nov. 2020].

Ricouer, P. (1984) Time and Narrative - Vol. I. Chicago and London: University of Chicago Press.

Schechner, R. (2006) Performance Studies - an introduction. 2. ed. New York/ London: Routledge.

Smallville (2001-2011) [TV programme] Hollywood: CW.

Sternberg, M. (1978) Expositional Modes and Temporal Ordering in Fiction. Baltimore: Johns Hopkins UP.

The Office (2005-2013) [TV programme] Hollywood: NBC.

Truby, J. (2007) The Anatomy of Story: 22 Steps to Becoming a Master Storyteller. 1st ed. [ebook kindle] New York: Faber and Faber.

Williams, L. (2001) Playing the Race Card: Melodramas of Black and White from Uncle Tom to O. J. Simpson. Princeton: Princeton University Press.

Williams, L. (2003) Film Bodies: gender, genre and excess. In. B. GRANT, ed., Film Genre Reader III. Austin: University of Texas Press. 
You (2018) [TV programme] Hollywood: Lifetime/Netflix.

\section{Biography}

Carolina Amaral holds a Master and a Doctorate in Film Studies from Universidade Federal Fluminense (UFF) in Brazil. Her PhD thesis examined narrative theoretical questions on romantic comedies. She is now developing a post-doctorate research on the topic of "Catharsis, narrative comfort and melodrama" at UFF. She teaches creative writing, narrative studies and screenwriting.

Email: carolinao@id.uff.br 